\title{
Analysis on the Status and Countermeasures of the Development of Pension Industry in Tianjin*
}

\author{
Meiqi Feng \\ Information School \\ Capital University of Economics and Business \\ Beijing, China \\ Cuiyou Yao** \\ Information School \\ Capital University of Economics and Business \\ Beijing, China \\ **Corresponding Author
}

\author{
Yanhong Yang \\ Information School \\ Capital University of Economics and Business \\ Beijing, China \\ Xingjia Yao \\ School of Economics and Management \\ Beijing University of Technology \\ Beijing, China
}

\begin{abstract}
Under the background of China's aging population and the coordinated development of BeijingTianjin-Hebei, the development of pension industry is not only an inevitable way to deal with the aging of population, but also an important measure to promote economic growth. Although the proportion of aged population in Tianjin has risen slightly, the process of aging is in the middle level of the country. Through the analysis of the pension industry in Tianjin, found that the relevant policies and regulations of Tianjin's pension industry were missing, and the development of home-based care services industry is low, and there were lack of the day care services, pension institutions and the resource utilization rate is not high. This restricts the development of the pension industry. Therefore, the government should increase policy support, improve relevant laws and regulations, establish and improve pension industry investment and financing system and industry standards, promote market-oriented operation and change the concept of home care for the aged.
\end{abstract}

Keywords-the aging of the population; pension industry; policy suggestions

\section{INTRODUCTION}

With the acceleration of the aging process of the population, the development of the pension industry has attracted much attention. After the coordinated development of Beijing-Tianjin-Hebei, the development of the pension industry in Tianjin is also worth our thinking. From 2001 to 2016, Tianjin accounted for over $10 \%$ of the population aged over 65 years old. The overall growth rate continued to grow. Although the proportion of aged population in Tianjin has risen slightly, the process of aging is in the middle level of the country. The main reason is that Tianjin is one of the municipalities directly under the central government. In recent years, with the development of economy, a large number of young migrant workers have reduced the actual

*This research was financially supported by Beijing philosophy and social science planning project (Project No. 17GLA084) and Beijing Municipal Education Commission on the social science program project (Project No. SM201810038001) aging degree, which has improved the situation. With the integration of Beijing-Tianjin-Hebei, and encouraging the aged in Beijing to live in different places, the pension pressure in Tianjin may be gradually aggravated. But there are still many problems in Tianjin's pension industry, which can't meet the needs of the aged. Through the analysis of the status of the development of the pension industry in Tianjin, this paper finds out the existing problems and gives some rationalization proposals.

\section{LITERATURE REVIEW}

According to the research of Tianjin pension industry, the government and scholars have made some research, mainly focused on the qualitative research. The Civil Affairs Bureau of Tianjin city summarizes the achievements of Tianjin in recent year, and introduces relevant policies. The number of beds and service levels of the pension institutions has been improved, and 10 community home care service models have been innovation to achieve the full coverage of home care services. However, there are still insufficient places to promote the legal process of the pension industry and improve the professional level of the service for the aged in the future. Zhang Xin, et al. (2015) combed the policies of the state and the pension in Tianjin, and found that from the Party Central Committee, the State Council to the local Party committee and the government, pension has been the top priority of the people's livelihood. However, the problem of aging can't be solved only by the government's corresponding policies and convenience measures, and it's also necessary for all social parties to join together. Yan Nan, et al. (2015) through the analysis of the current situation of the pension model development in Tianjin, found that excessive aging, lack of financial input, pension reserve enough, and the old idea and other reasons restricted the development of the pension industry in Tianjin. The government should strive to development human capital, improve the national pension system, and encourage selfpension, in order to ease the pressure of the pension industry 
development in Tianjin. In addition, Zhang $\mathrm{Na}$ and others (2014) found that the public service facilities of the old age community were not matched, and put forward a "feasible, replicable and sustainable" innovation mode to drive the development of the pension industry in Tianjin. Tianjin city has made many achievements in terms of endowment undoubtedly, but in the face of the growing pressure of pension, these achievements are not worth mentioning, the development of Tianjin pension industry still exists many problems. The government needs to introduce relevant policies in the future, and the need for the participation of social forces, in order to alleviate the financial pressure of the government.

\section{The Status Quo of Population AgIng In TIANJin}

Under the background of China's aging population and the coordinated development of Beijing-Tianjin-Hebei, the development of pension industry is not only an inevitable way to deal with the aging of population, but also an important measure to promote economic growth.

According to the international definition of the aging society, a region over $7 \%$ of the population over 65 years old is considered to have entered an aging society. According to this definition and the relevant data of Tianjin $2006 \sim 2016$ in the population sampling survey, the trend map of "Fig. 1" is obtained.

According to the "Fig. 1", from 2001 to 2016, the proportion of elderly people over 65 years old in Tianjin is basically above $10 \%$. On the whole, the trend of sustained growth is maintained, and the growth rate is slow. According to the survey, Tianjin as a municipality directly under the central government, as early as 1995 , the population ratio of 65 years old and above has reached $8.15 \%$, and it has entered an aging society earlier.

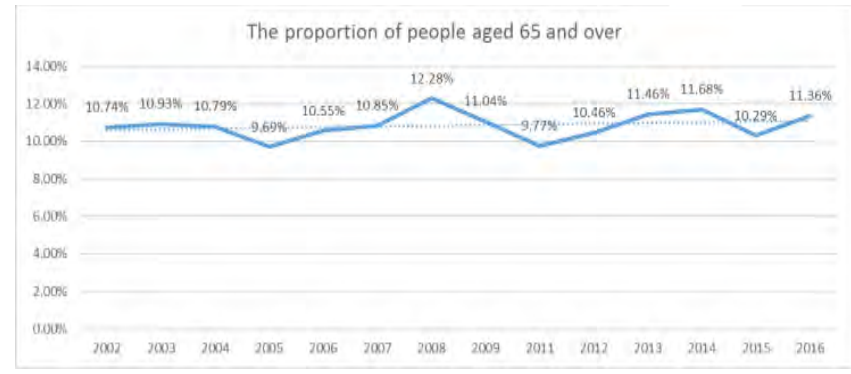

Fig. 1. Age 65 and older population ratio.

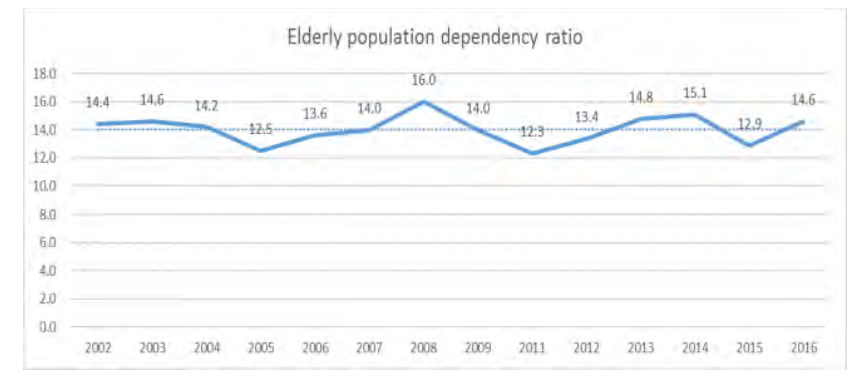

Fig. 2. Elderly population dependency ratio.
At the end of 2017, the population aging process in Tianjin was in depth, and the population of 65 years old and above was 1 million 576 thousand and 700 people, accounting for $10.13 \%$. The aged dependency ratio was raised by $12.71 \%$, which was 0.23 percentage points higher than that of the previous year.

Although the proportion of elderly population in Tianjin has increased by a small margin, the aging process is at the national level. The proportion change is also the lowest level in China except Shanghai. The main reason is that Tianjin is one of the municipalities directly under the central government. In recent years, with the development of economy, a large number of young migrant workers have reduced the actual aging degree, which has improved the situation. According to the data of "Fig. 2", the aged dependency ratio in Tianjin in recent years shows a trend of decreasing and increasing, and the burden of the aged is increasing. It is predicted that at the end of the "13th FiveYear", elderly population will reach 2 million 730 thousand in Tianjin, the proportion of the total population will be over $25 \%$. The aging of the population in Tianjin shows that the aged population is increasing rapidly and the scale is large. The aged and disabled are growing quickly, and the social burden is heavy. And the rural elderly problem is outstanding. In addition, the aged families have the characteristics of empty nest and accelerated solitude.

According to the forecast, the aging of Tianjin will also enter a high growth period in the future. At the same time, the rapid growth of the aging population overlapped the problems of family size and empty nest. With the increasing pace of industrialization and urbanization in Tianjin, the demand for social endowment insurance in the city expanded rapidly. It can be seen that only by correctly handling the relationship between population aging and social economic development, can we ensure the basic life of the aged family and the aged, and promote the development of the pension industry.

\section{The Status Quo of The DeVElopment of THE PENSION INDUSTRY IN TIANJIN}

In China, the main ways of providing for the aged are home care, community centralization and institutional pension. Home care is a social service for the aged living at home, which is based on family centered, community and professional services. Community-based old-age care is the introduction of services to institutions in the community, and the implementation of community endowment at home is the advantage and maneuverability of attracting family support and social endowment, concentrating the best combination of family pension and institutional endowment in the community. Institutional pension is a proper noun for the aged, which is provided the daily life, sanitation, life care, health management and entertainment integrated services for the aged.

\section{A. The Present Situation of the Implementation of the Relevant Policies for the aged in Tianjin}

In recent years, China has initially established a social pension service system supported by home care services, 
community based pension services and institutional pension services. Governments have also promulgated relevant policies to support the development of the pension industry.

In April 2011, the Tianjin municipal government issued the "On the further development of home-based care services in Tianjin city" (No 51, [2015]). It is clear the specific measures to support home-based work in the "13th Five Year" period.

In August 2011, the municipal government issued the "planning layout of civil service facilities in Tianjin city (2010-2020)" (No 102, [2011]). It provides layout planning for the pension service facilities, and integrates the construction of the pension service facilities into the urban control planning, providing a strong planning support for the construction of the pension service facilities.

According to the plan, by 2015, Tianjin has basically formed the "973" old-age service pattern, that is: of the aged in the city, $97 \%$ of the aged live at home, and $3 \%$ of the aged live in the pension institutions. It is a social old-age service system with the characteristics of Tianjin, which forms the diversification of the investment subject and the diversity of the service content to meet the needs of the aged.

In May 2012, the Municipal Civil Affairs Bureau combined 12 relevant departments issued "on the development of disability services of the aged in Tianjin city" (No 42, [2012]). It is clearly the 8 support measures.

In September 13, 2013, the State Council issued the "opinions on accelerating the development of the pension service industry", and put forward the general requirements, main tasks and policy measures to accelerate the development of the pension service industry. It puts forward "a comprehensive system of home-based, community-based and institutional support, with a perfect, moderate scale and an old-age service system covering urban and rural areas, was completed in 2020." At the same time, the opinion put forward the general requirements, tasks and policies and measures to accelerate the development of the pension service industry, releasing many good signals for social forces and private capital to enter the pension service industry in terms of policy guidance, mechanism building and pilot timing.

The introduction of national policies has provided a clear guidance for the formulation of local policies in all provinces and municipalities, and provided new vane for the optimal allocation of market resources, and also brought new opportunities for the whole pension industry market. In the course of policy implementation and refinement in the next one or two years, the old-age industry market will usher in a policy-based reshuffle.

However, in general, the supply of old-age service in China is still inadequate and the policy of supporting the oldage service has not been perfected. The Tianjin municipal government has also issued many policy documents related to the pension industry, but has not yet formed a complete policy system, and only put forward the corresponding policy documents for a specific aspect, and needs to form a complete pension service related policy system.

\section{B. The Status of Community Home Care Service in Tianjin}

First of all, the government provides government subsidies and nursing subsidies for the home care service for the 7 types of elderly people who need living care. The subsidy is issued to the old man in the form of service voucher, and the service item is chosen by the old man independently. Since the implementation of the family pension government subsidy policy, it has solved the problems of housekeeping service and nursing care for the aged. At the same time, the government also provides age subsidies for elderly people. The specific criteria are shown in "Table I".

TABLE I. TIANJin AgE Subsidy StANDARD

\begin{tabular}{|c|c|c|c|}
\hline City & $\begin{array}{l}\text { Scope of } \\
\text { subsidies }\end{array}$ & $\begin{array}{l}\text { Subsidy } \\
\text { amount }\end{array}$ & Remarks \\
\hline \multirow{4}{*}{ Tianjin } & $\begin{array}{l}100 \text { years old and } \\
\text { above (household } \\
\text { registration) }\end{array}$ & $\begin{array}{ll}500 \text { yuan } & \text { per } \\
\text { person } & \text { per } \\
\text { month } & \end{array}$ & \\
\hline & $\begin{array}{lcr}\text { Above } & 60 & \text { and } \\
\text { under } 70 & \text { years } \\
\text { old } & & \end{array}$ & $\begin{array}{ll}95 \text { yuan } & \text { per } \\
\text { person } & \text { per } \\
\text { month } & \end{array}$ & \multirow{3}{*}{$\begin{array}{l}\text { With the city's } \\
\text { household } \\
\text { registration for } \\
\text { more than } 20 \\
\text { years, no basic } \\
\text { endowment } \\
\text { insurance and } \\
\text { social } \\
\text { endowment } \\
\text { insurance }\end{array}$} \\
\hline & $\begin{array}{l}\text { Above } 70 \text { and } \\
\text { under } 80 \text { years } \\
\text { old }\end{array}$ & $\begin{array}{ll}105 \text { yuan } & \text { per } \\
\text { person } & \text { per } \\
\text { month } & \end{array}$ & \\
\hline & $\begin{array}{l}\text { Above } 80 \text { years } \\
\text { old }\end{array}$ & $\begin{array}{ll}115 \text { yuan } & \text { per } \\
\text { person } & \text { per } \\
\text { month } & \end{array}$ & \\
\hline
\end{tabular}

But for the monthly per capita cost of older people, the government's subsidy is a drop in the bucket. Due to the fact that China has made it unable to spend too much money on the welfare system such as the pension system, the financial support for the aged has a certain scale, but it is not enough for the development of the pension industry.

In addition, from 2009, Tianjin is going to use 3 years to build community day care centers in 107 neighborhoods and 137 townships in the whole city, and build 300 elderly daytime care service stations in communities and natural villages. In March of the same year, the Tianjin Municipal Civil Affairs Bureau, Finance Bureau, labor and Social Security Bureau jointly issued the "the implementation opinions on the construction of the aged day care service center (station)". The document clearly points out that we need to establish and improve the community care service system for the aged in the community with life care, old people dining, medical rehabilitation, spiritual comfort as the main function, and life difficult, and mobile inconvenient and empty nest elderly as the main objects. At the same time, the document also stipulates the scale of the construction of the care service center for the aged. It stipulates that its construction scale is no less than $300 \mathrm{~m} 2$, and the specific area of lounge, dining room, recreation room, fitness and rehabilitation room, health care room, and senior citizen school has been stipulated accordingly. In 2011, the Tianjin municipal government issued "the opinion on the further development of the service for the aged in our city", issued a series of support for home care policy: the city government gives a one-time subsidy of 300 500 thousand yuan for each elderly day care center, welfare lottery for each served give a 
one-time funding of 10 thousand yuan per bed. Up to now, Tianjin has built 577 old day care service centers and service stations.

Although daytime care centers have been opened a lot, the number of people actually enjoyed is very small. This is mainly due to the lack of publicity in the community and the traditional ideas of the aged. In the traditional Chinese culture of providing for the aged, the concept of family support is deeply rooted. It enters the day care center, which is harmful to the self-esteem of the aged, and let the neighborhood mistake their children's filial piety as a psychological obstacle to enter.

\section{The Status Quo of Tianjin Institutional Pension Service}

Tianjin basically formed a "973" old-age service pattern, $3 \%$ of the aged in the pension institutions for the aged. It is understood that as of 2015, 64651 beds for the aged in Tianjin. In the last five years, the average annual growth rate of the bed was $20 \%$. The average number of thousands of elderly people had 30 beds. 398 pension institutions have been built. Among them, there are 279 maintenance types, 89 support type, 30 medical care; 89 in rural areas, 309 in cities and towns; 162 new houses were built and 236 were expanded.

According to the rate of bed growth in 2015, by the end of 2016, there were less than 100 thousand beds in Tianjin for the aged, but the aged 60 and above had exceeded 2 million 439 thousand.

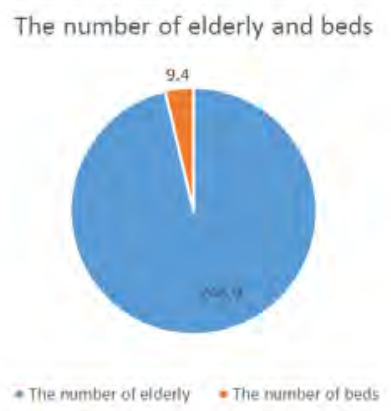

Fig. 3. The number of the aged and beds.

By the end of 2015, there were only 398 pension institutions in Tianjin. The proportion of beds available to the aged is less than $4.1 \%$. It can be seen that the gap between the aged nursing homes in Tianjin is quite serious.

At present, the aged apartment in Tianjin is in a tight bed. There is a lot of registration in the queue. Especially, the office of the State Pension Institute lacks beds. From this point of view, private nursing homes still have their own market share. After all, this is a choice for the future of the aged.

Besides, according to the survey, 93.6\% of the aged do not want to live in the nursing home, and their children have no related intentions. The reason is relatively simple. One is afraid of being filial piety. Two, the cost of the nursing home is relatively high, and the aged or their children can't afford it.
For the aged who have willing to go to pension institutions, more than $50 \%$ of the survey shows that they are willing to pay 1000 yuan 1500 yuan per month, while the lowest cost for a disabled elderly is 2700 yuan, which is very large. This also restricts the development of institutional pension.

\section{The Problems of the Development of the PENSION INDUSTRY IN TIANJIN}

\section{A. The Lack of Policies and Regulations Restricts the Development of the Pension Industry}

In recent years, the relevant departments and governments all over the country attach great importance to the research and formulation of policies and regulations for pension services, to a certain extent, regulate and promote the development of the pension service industry. But because of the rapid economic and social development in China, the existing policies and regulations are only stipulated from the principles, lacking systematic and systematic legal provisions. Some laws and regulations are quite different from local reality, which is difficult to implement. Especially for the development of private pension services, there is a lack of foresight. There are few policies and regulations, and lack of effective regulations and regulations. The construction of social pension service system is lagging behind the current level of economic and social development.

\section{B. The Development of Home Care Service Is Slow and the Day Care Service Is Lacking}

Since 2006, Tianjin has launched the pilot project of home care services for the aged with difficulty in the Heping District and Tanggu District, but is has not been promoted in the whole city. The main reason is that the subsidy policy for the aged is not yet implemented. In addition, elderly people living in the home have difficulties such as illness, inconveniences and so on, and need to be taken care of the day. However, the existing "Xingguang old people's home" and "community service center" and other pension service institutions are affected by personnel and funds, some of them are shelved all the year round, others are subleasing other people, and they have not played their due role.

\section{The Resources of the Pension Institutions Are Tight and the Utilization Rate Is Not High}

At present, there is a serious imbalance between the growing demand for pension services and the limited supply of old services in Tianjin. The stock of the existing pension institutions does not match the actual and potential huge pension needs. In the end of 2017 , the population aging process was in depth in Tianjin. The aged population aged 65 and over is 1 million 576 thousand and 700. However, according to the growth rate of the number of beds in the pension institutions in 2015, the number of beds in the pension institutions in 2017 is still less than 100 thousand, which is far from the number of the aged in Tianjin. But the number of people living in the pension institutions is about half, the total occupancy rate is $54 \%$, and nearly half of the beds are idle, and there is a waste of resources. This is enough to show that the supply of pension institutions in Tianjin is insufficient and the utilization rate is not high. 


\section{COUNTERMEASURES AND SUGGESTIONS FOR THE DEVELOPMENT OF PENSION INDUSTRY IN TIANJIN}

\section{A. Strengthening Policy Support and Perfecting Relevant} Laws and Regulations

Through national legislation, we can ensure the standardization and sustainability of the development of the pension industry in the form of laws and regulations, so as to realize the legal and legal basis of pension industry. On the basis of existing laws and regulations related to pension services, according to China's national conditions, national strength, pension culture and the needs and status of the aged's support and care, we defined pension industry status, government, family and social responsibility, the content and the way of pension services, pension services procedures, norms and standards, pension industry sources of funding, service facilities and human resources development and construction, non-profit organizations and enterprises to participate in the policy, the government supervision, the pension industry and quasi exit mechanism, which to ensure the sustained and healthy development of the old-age service and the industrial chain of the aged in China. We should change the status quo that comprehensive legislation too general, the special legislation not system, the legislation level too low. In addition, we will formulate laws and regulations such as the pension industry law and the pension service law, and introduce relevant supporting laws and regulations to form a system to improve the legal system of the pension industry.

\section{B. Establishing and Perfecting the Investment and Financing System and Industry Standard of the Pension Industry}

The government should increase the financing support for the private pension institutions and their construction projects. The financial institutions should give the preferential policy of interest rate, relax the loan conditions, improve the investment and financing system, and cultivate the diversified investment and financing bodies. The financial departments should give necessary discount loans and credit guarantees to support the needs of the market, large scale and better prospects for the old-age service projects. The government needs to rationally optimize the social financial resources, mainly through finding alternative resources, optimizing the way of resource combination and improving the efficiency of resources operation. We should rationally allocate various resources to improve the macro efficiency of the pension industry, solve the problem of future social pension resources and improve the utilization ratio of funds through technological equipment instead of human input. The government should formulate a forwardlooking social policy for resource allocation, give consideration to the equity and efficiency of the whole social pension industry, and actively encourage social forces to participate in the pension industry, and private capital and organizations can implement multiple services. The government can draw on some mature industry standard and evaluation system of the old age industry and formulate the index that is suitable for our country's qualification authentication, business location construction, and equipment delivery and operation evaluation.

\section{Promoting the Market Operation and Changing the Concept of Home Care for the Aged}

The community should strengthen the community homebased care propaganda, change the traditional concept of retirement, and so that enterprises can focus more on the "sunset red" the economic industry in the process of propaganda, to expand services for the aged, and increasing service needs, to achieve economic benefits and win-win social benefits. At the same time, we should publicize the mode of community home care, strengthen the attention of all walks of life to the pension industry, and actively encourage enterprises and institutions, social organizations and individuals to donate materials to the community home care service stations, or to provide free services. And the government should also invest more money in the community for the aged so that the aged can easily enjoy the corresponding service provided by the society.

\section{CONCLUSION}

In the process of Beijing-Tianjin-Hebei integration, there are still many problems. In order to solve these problems and promote the integration process of Beijing, Tianjin and Hebei, the government's input is still needed. Whether in policy or finance, the government's role is indispensable. In addition, the government should encourage more private capital to enter the pension service industry in order to alleviate the financial pressure of the government and better develop the pension service industry.

\section{REFERENCES}

[1] Zhang Xin, Liu Jizhi. "Literature review of the pension policy in China and Tianjin," Modern Enterprise Culture, China, pp. 125-126, 2015.

[2] Zhang Yuqi. "Analysis of the influence of population aging on consumption structure in Tianjin," Tianjin University of Finance and Economics, China, 2016.

[3] Wang Jun. "Research on the improvement of pension insurance with commercial insurance under the background of population aging Taking Tianjin as an example," Tianjin University, China, 2015.

[4] Yang Nan, Liu Jizhi. "The problems and Countermeasures of Tianjin's old-age mode in China," China Business Update, China, pp. 50-51, 2015

[5] Tianjin Civil Affairs Bureau. "Tianjin: the successful exploration of the service for the aged," China Social Welfare, China, pp.33-34, 2015.

[6] Zhang Na, Wang Chao, Liu Jian. "Research on the standard of supporting public service facilities in Tianjin pension community," Annual meeting of China's urban planning, China, 2014

[7] Wang Lili, Chen Gang, Wu Xiaolan. "The construction of daytime care center for the aged in community under the concept of community care," Journal of Henan University of Technology, China, pp. 46, 2011

[8] Liu Nan, Yang Yuanyuan, Zhang Haili, et al. "The investigation and analysis of the running status of the daytime care center in Tianjin," Medical Information, China, 2015.

[9] The first class of the Party School of the CPC Tianjin municipal Party committee, a class of "Research on the problem of social construction", Zhang Dianjun, Li Yujie, etc, “An investigation report 
on the status of the service for the aged in Tianjin", Knowledge, China, pp. 33-35, 2016.

[10] Li Ping, Liu Hongyi, Zhu Zuoying. "Take various measures to speed up the development of Tianjin's old-age service industry," Tianjin Economy, China, pp. 58-60, 2007.

[11] He Ling. "Research on the problems and Countermeasures of Tianjin pension service institutions," Modern Business Trade Industry, China, pp. 37-38, 2015. 